\title{
HIVIAIDS Awareness and its Impact on the Profitability of Business Firms in Developing Nations
}

\author{
Cynthia Udeh \\ Wilhelmina Smith \\ Herring Shava* \\ Department of Business Management, University of Fort Hare, \\ P. Bag X1314, Alice, 5700, South Africa \\ *Email: hshshava@gmail.com
}

\section{Doi:10.5901/mjss.2014.v5n7p244}

\section{Abstract}

The impact of HIVIAIDS on South Africa as well as in the African continent is undoubtedly enormous, especially considering the percentage of the country's workforce living with HIVIAIDS. This study becomes imperative when statistics shows that many owners/managers are not well aware of the challenges of HIVIAIDS in their business firms. This study investigated HIVIAIDS awareness and its impact on the profitability of business firms in King Williams Town, Eastern Cape, South Africa, which could well relate to developing nations. The researchers use a target population of all the private business firms as well as the owners/mangers that are present in King Williams Town. A sample was drawn from the target population by the researchers. The sample size of 120 respondents (100 employees and 20 owners/mangers) was considered adequate due to the sensitive nature of the research. Based on the findings of this research, it was discovered that employees of business firms are not aware of issues pertaining to HIVIAIDS, business firms do not have a workplace policy on HIVIAIDS to minimise the impact of HIVIAIDS and HIVIAIDS does affect the profitability of business firms in developing nations. The study recommends that business firms and relevant stakeholders develop effective strategies in minimising the impact of HIVIAIDS at work place and on employee morale as well as to intensify HIVIAIDS awareness campaigns at firm level.

Keywords: Investors, revenue, employees, productivity, mixed-method, workshops, workplace

\section{Introduction}

The occurrence of HIVIAIDS presents a global health and social crisis and presents a critical health and economic concern in South Africa. It was estimated that 33.3 million people were living with HIV globally at the end of 2009, compared to 26.2 million in 1999 - showing a 27\% increase (United Nations Acquired Immunodeficiency Syndrome Report (UNAIDS), 2010). Although, the global number of new HIV infections has steadily declined since the late 1990s, this decrease is offset by the reduction in AIDS-related deaths, due to the significant scale-up of Anti-Retroviral Therapy over the past few years (UNAIDS, 2009).

Sub-Saharan Africa is the epicentre of the pandemic and still bears an inordinate share of the global HIV burden. In 2009, it was estimated that about 22.5 million people, amounting to $68 \%$ of the global total of people with HIVIAIDS, resided in Sub-Saharan Africa. It is also estimated that 1.3 million people died in Sub-Sahara in the same year under review, comprising about $27 \%$ of the global total of 1.8 million deaths attributable to the epidemic (UNAIDS, 2009).

The South African National HIV prevalence is around $11 \%$ with an estimated 5.6 million people living with HIV in 2009, compared to 5.2 million in 2008, showing that South Africa's epidemic figures remains the highest in the world. It was reported that an estimated 310000 South Africans died of AIDS-related illnesses in 2009 (SA DOH, 2009; Statistics South Africa, 2009). The above mentioned studies show that the HIVIAIDS prevalence among individuals aged between 15 and 49, comprising the majority of the country's workforce, is around $17.8 \%$. In addition these studies also reveal that one out of three women aged between 25 and 29 and over a quarter of men aged between 30 and 34 are living with HIV.

This spread of HIVIAIDS has unfortunately resulted in the loss of revenue to affected firms. This loss is attributable to the increased expenditure on employee benefits such as health care costs, sick leave, death benefits as well as to the additional cost of retraining new employees. Business revenue also could show a decline when many workers become infected and resultantly their productivity could decline (USAIDS/African Bureau, 2000). 
On the other hand, Africa, as a developing continent, needs to attract new and foreign investors in order to demonstrate a competitive advantage. Most African countries already have a competitive advantage because labour is abundant, affordable and productive. Countries in the Sub-Sahara, including South Africa, inevitably compete against one another to attract investors. These investors, in turn, seek to locate their businesses in a country that has the most productive and lowest cost workforce (USAID/African Bureau, 2000).

The above factors support the fact that the entire impact of HIVIAIDS on businesses cannot be quantified. It is thus the intent of this research to determine the impact of HIVIAIDS on the profitability of business firms in King Williams Town, South Africa, which could then affect emerging economies in a similar manner.

\subsection{Problem investigated}

In this stage of the HIVIAIDS epidemic, business firms can no longer afford to ignore it, as its impact on businesses is enormous. Although, many firms have undertaken studies on the impact of HIVIAIDS on their workplace and productivity, unfortunately the result of most of the studies are not available to the public. Nevertheless, the available results of few studies, points to a serious impact of HIVIAIDS on businesses in some settings and indicates the potential for the effect to grow rapidly as the epidemic advances (UNDESA, 2002).

A review by Bloom, Mahal and Path River Associates (2001, p.8 and 12.) characterised the literature on AIDS and Business as "remarkably thin", with many completed studies having small sample sizes and a narrow focus on one or two industries in particular. In addition, most of the stronger studies pertain to the early 1990s, a time when the epidemic was only beginning to have a noticeable effect on many countries. Bloom et al. (2001, p. 8 and 12.) also found a pattern of small, but significant impacts and observed that, "as the epidemic deepens, so will its effect on businesses change, meaning that some of the more extensive studies may have little to tell about the current situation, let alone the effect of the impact that business will have to face in ten years' time."

When the above statistics are taken into account, the impact of HIVIAIDS on Africa is undoubtedly enormous, especially considering the percentage of the continent's workforce living with HIVIAIDS. It is also clear that HIVIAIDS in a wider context will affect relations, morale and productivity within the business firms. It will also ultimately lead to an increase in the amount of sick and compassionate leave required by staff. In the event of an employee not being infected personally, he or she would request time off to attend funerals or care for members of the family who may be ill. Denying employees these rights or taking disciplinary action against them, will probably contravene Labour Relations' Laws and this is why one of the main objectives of this research was to determine the impact of HIVIAIDS on business firms, especially those in developing nations, in order to offer good advice to owners/managers on the best HIVIAIDS practices.

The losses due to HIVIAIDS are mainly through reduction in productivity, loss of organisations' key personnel owing to death of key staff members, settlement of death benefits and increased cost of recruitment. Many health consults opined that if people infected with HIV are not allowed to fall sick, there will be no payment for treatment or more death benefits, and they will stay at work, which means they are self-supporting and do not present a burden to the business and society (Aaron, 2007).

This study becomes imperative when statistics shows that many owners/managers are not well aware of the challenges of HIVIAIDS in their business firms. Few business firms are equipped to handle HIVIAIDS-related cases in their business areas, while the majority is less clear about how and in what way the epidemic is developing and what impact this will have on their business operations. This is why many businesses today are still operating without having an effective company or firm policy on HIVIAIDS (International AIDS Economic Network (IAEN), 2002).

\subsection{Objectives}

The following objectives were formulated:

- To examine whether employees of business firms in developing nations were aware of issues pertaining to HIVIAIDS.

- To examine whether business firms in developing nations had any workplace policy on HIVIAIDS that seek to minimise its impact.

- To determine whether there is a relationship between HIVIAIDS and profitability of firms in developing nations.

\section{Literature Review}

The effect of HIVIAIDS has inevitably changed the dynamics involved in the international competitiveness of African 
businesses. It also affects the labour supply due to increased deaths leading to a reduction in the available workers. It affects profits by reducing the profitability of African businesses by both increasing the cost of production and decreasing the productivity of workers. As said before, the total impact on businesses is difficult to quantify (USAID, 2001).

The former president of the World Bank Group, Wolfenson, was quoted by the Business Response to HIVIAIDS (2000) saying, "HIVIAIDS is a major development challenge confronting people in Africa today." According to Business Response to HIVIAIDS (2000), it is possible to identify two broad areas in which HIVIAIDS impacts on individual business operations, which is on productivity and increased costs. It is also clear that basic principles combined with extensive experience, clearly provide the direct link between HIVIAIDS, declining productivity, rising production costs and a decline in company profits (Business Response to HIVIAIDS, 2000).

\subsection{Conceptual Framework}

The study extends to the socio-economic impact of the HIVIAIDS epidemic on firms, a conceptual framework developed by the UNAIDS, Global Business Council on HIVIAIDS and Prince of Wales Business Leaders Forum (2000) outlined in their study "The Business Response to AIDS: Impact and Lessons Learned." The framework is outlined in figure 1. The outlined conceptual framework attempts to analyse the impact of HIVIAIDS on firms. Loewenson and Whiteside (1997) however argue that the impact of HIVIAIDS depends primarily on five factors namely: the number of people infected in the business enterprise; their respective roles in the firm; the design of the production process and its ability to survive worker absenteeism; benefits packages offered by the firm; and the effect on the business environment of HIVIAIDS on other stakeholders such as other firms and government. In the framework, the effects of absenteeism and deaths are evident when HIV infection has intensified. Affected workers find it difficult to attend to their normal duties leading to prolonged absenteeism which has negative effects on productivity particularly if it is the firm's key employees who are affected. Furthermore, AIDS deaths occur predominantly among workers who are in their most productive years. To compensate for lost personnel, firms recruit younger and less experienced workers; resultantly worker productivity may be reduced. In other words, firms inevitably face growing demand for recruiting and training in order to replace the dying and ailing personnel (UNDESA, 2002, p.53).

Figure 1: Conceptual framework for the socio-economic impact of the HIVIAIDS epidemic on firms

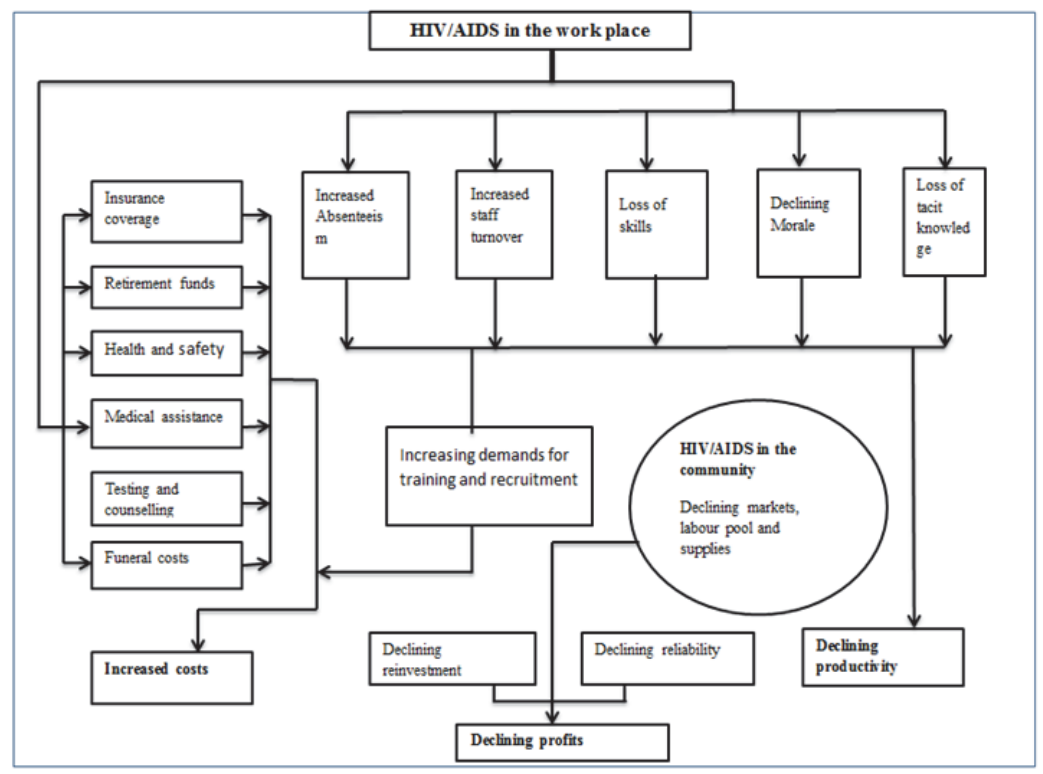

Source: UNAIDS, Global Business Council on HIVIAIDS and Prince of Wales Business Leaders Forum, The Business Response to AIDS: Impact and Lessons Learned (Geneva, 2000). 
The UNDESA (2002, p.53) further suggest that, business enterprises that have health programmes may find themselves channelling significant amounts towards medical costs. Given that insurance firms increase the costs of coverage in response to high HIV prevalence rates which is certainly the case with insurance firms because of the nature of their business, insurance schemes for business enterprises may turn out to be more expensive than anticipated. In addition, high costs could deplete firm revenue reserves aimed at future reinvestments and as for the employees; HIVIAIDS related consequences include increased funeral costs. Moreover, as co-workers fall sick and die, morale and productivity of surviving employees may be severely affected.

On the other hand, HIVIAIDs epidemic negatively affects the community at large by impoverishing the households leading to decreased demand of goods and services. Unfortunately, firms specialising in producing those goods and services may suffer from declining consumer base resulting in declining profits (UNDESA, 2002, p.53).

The impact of HIVIAIDS further spills over to the economy if proper measures are not put in place. A study by Arndt and Lewis (2000) reveals the macro implications of HIVIAIDS. However, a study by Biggs and Shah (1997) using primary data survey from five-Sub-Saharan African countries, covering 992 firms with total employment of 115136 workers report the effect of AIDS epidemic on firms to be minor.

When the above background is being considered, it can be understood that the spread of HIVIAIDS has resulted in the loss of profitability of South African firms and the probability is high that firms in developing nations are also experiencing the same challenge. This loss being attributable to the increased expenditure on benefits such as healthcare cost, sick leave, death benefits as well as the additional cost of retraining new employees (USAID, 2000). Revenue has also shown a decline when many workers become infected and their productivity declines (USAID/African Bureau, 2000).

For this very reason, businesses are advised to minimise these effects by responding to issues concerning HIVIAIDS which can be achieved through the use of effective HIVIAIDS workplace policies and programmes. This advice arose because it was discovered that the response of corporate South Africa to HIVIAIDS has been 'slow, partial and erratic and somehow guarded' (Dickinson, 2004, p.17).

In a study by the South African Business Coalition on HIVIAIDS (SABCOHA), (2003), which focused on large firms in South Africa, it was reported that less than two thirds of the largest firms in South Africa are making use of HIVIAIDS Policies and Programmes (Bendell, 2003, p.13). This information depicts the unpreparedness and lack of HIVIAIDS awareness among business firms in South Africa and other developing nations about the impacts of HIVIAIDS on businesses. Results about such issues could only be ascertained by making use of a certain research methodology.

\subsection{HIVIAIDS Defined}

According to Root-Bernstein (1993) there is no unique definition of HIVIAIDS as the definition of HIVIAIDS has evolved along with the disease itself. The author states that the first definition for HIVIAIDS was published by the Centre for Disease Control (CDC) (1985, p.373). The CDC defines HIVIAIDS as a disease, at least moderately predictive of a defect in cell mediated immunity, occurring in a person with no known cause for diminished resistance to that disease. Such diseases include Kaposi's sarcoma, Pneumocystis carinii pneumonia, and serious other opportunistic infections. These infections include pneumonia, meningitis, or encephalitis. This definition was heavily criticised as it is evident from the definition that the CDC was not sure what HIVIAIDS was in 1982, other than that it appeared to be due to immune deficiencies of unknown cause that could be manifested by any of the fourteen different opportunistic diseases listed in the CDC report.

Weiss (1993) defines Human immunodeficiency virus (HIV) as a lentivirus (a member of the retrovirus family) that causes an acquired immunodeficiency syndrome (AIDS), a condition in humans in which progressive failure of the immune system allows life-threatening opportunistic infections and cancers to thrive. Infection with HIV occurs by the transfer of blood, semen, vaginal fluid, pre-ejaculate, or breast milk. Within these bodily fluids, HIV is present as both free virus particles and virus within infected immune cells.

UNAIDS (2001, p.11) define HIVIAIDS as a pattern of infections or diseases that attack the human body after the HIV virus has disabled the human immune system in the fight against such infections. People with HIV may lead healthy lives with no symptoms for years before they develop AIDS. The period of being healthy varies among individuals, but eventually the virus becomes activated and progressively leads to the serious infections and other conditions that characterise AIDS. Even though there are treatments that can prolong an infected individual's life, the end result of AIDS is death (UNAIDS 2001, p.11).

On the other hand, the World Health Organisation (WHO) (2005) define human immunodeficiency virus (HIV) which causes acquired immunodeficiency syndrome (AIDS) as a disease that attacks the human immune system and 
renders the person more susceptible to a wide variety of opportunistic infections and malignancies. According to WHO, the definition of HIVIAIDS should include any person who has developed a significant loss of a particular type of white blood cell called T-helper lymphocytes. Normally, a healthy person has a T-helper lymphocyte count of around 1,000 cells per cubic millimetre of blood. AIDS may now be diagnosed when the number of these T-helper cells falls below 200 per cubic millimetre of blood if the individual is HIV seropositive and even if he or she has no opportunistic infections. Conclusively, it can be agreed that there is no unique definition of HIVIAIDS as the definition of HIVIAIDS has evolved along with the disease itself as stated by Root-Bernstein (1993).

\subsection{HIV/AIDS as a management issue}

The United Nations regard HIVIAIDS not only as a health issue but an issue that cuts to the core of business practice (UNAIDS, 2000, p.2). Given all these realities, the focus of sustainability reporting on HIVIAIDS has been seen as an important aspect of business and what firms are doing (Fakier, 2004, p.90). According to Dr. Cronson of Health InSite (reported in Lundin 2003), the Human Resources Department of a business is usually faced with the task of dealing with HIVIAIDS infected employees. The reason is that HIVIAIDS is seen as a Human Resources problem or a social investment issue.

Dr. Cronson (reported in Lundin, 2003), criticised the above notion and suggested that HIVIAIDS must be a toplevel core strategy issue, which therefore needs the involvement of employers (cited in Naidoo, 2005, p.27). Reassigning, accommodating, reducing or restructuring benefits and dealing with employees' fears and concerns raise legal and moral issues that challenge businesses which have employees affected with HIVIAIDS (Petesch, 2003).

Fraser-Moleketi (2000) stated that the fact that employers who have knowledge about HIVIAIDS and who are able to quote statistics, is not adequate. In order to have knowledge about HIVIAIDS as it applies in the workplace, they also need to undertake a hands-on approach in the implementation of development policies and managing programmes.

It is recognised that the way employers address HIVIAIDS in the workplace, will determine whether their companies survive the first decade of the $21^{\text {st }}$ century. It is expected that there will be 580,000 new cases of HIVIAIDS yearly in South Africa and a life expectancy of 38 years by 2010 as reported by Hawthorne (1999), a fact which could also be applied to the rest of the African continent.

The Asian Business Coalition on AIDS $(2002$, p.1) indicates that three crucial reasons exist as to the reason why HIVIAIDS is an issue for all businesses, namely: HIVIAIDS mostly occur in productive people aged between 15 to 49; transmission of HIVIAIDS is increasing as the number of HIV-positive workers and consumers increases, hence all businesses will be affected; and lack of awareness and understanding of HIV, resulting in fear and negative attitudes among employees and employers, can cause workplace conflict as well as stigmatisation, discrimination and mismanagement of HIV-positive employees.

Additionally, business productive information, intellectual property and performance continuity are a threat to firms, especially those that provide services which require in-depth knowledge. Hence, the need exists for employers and the Human Resource Department in re-assigning, accommodating, reducing or restructuring as well as dealing with employees' fears and concern about HIVIAIDS and its legal and moral issues which challenges businesses (Petesch, 2003, p.14).

HIVIAIDS has an impact on a firm's profitability, by either increasing or decreasing revenues. Increasingly, businesses are becoming aware of the impact HIVIAIDS will have on their profitability, in some cases, it is an awareness that is long overdue. The challenges of HIVIAIDS and its impact are not only seen as a medical issue but have become a much broader threat to communities, businesses and the economy (The Pan African Health Congress News, 2008). Research conducted by the SA Business Coalition on HIVIAIDS and the Bureau for Economic Research in Stellenbosch indicates that $55 \%$ of mines, $46 \%$ of transport companies and $38 \%$ of manufacturers have noticed a drop in profits due to the AIDS pandemic (Whitefield, 2005).

On the other hand, studies concerning the impact of AIDS on profitability in Africa have had mixed results. Studies completed in South Africa, (Morris, Burdge and Cheevers, 2000) and Kenya (Roberts et al. 1996) suggested that the economic impact of HIVIAIDS on profitability was likely to be substantial. On the contrary, studies in Zambia (Smith and Whiteside, 1995), Malawi (Jones, 1996) and Botswana (Greener, 1997) indicated that the impact of HIVIAIDS on profitability was not substantial.

\section{Research Methodology}

A specific research methodology was applied in the conduction of this research in an effort to determine HIVIAIDS 
awareness and its impact on business firms. The research adopted the mixed-method approach that is the use of both quantitative and qualitative methods which involved a well-structured questionnaire that was administered to the employees as well as the utilisation of personal interviews with employers of randomly selected private business firms in King Williams Town. The use of a mixed-method approach allowed researchers to implement a quantitative research design which enabled numerical statement of the facts, claims and assertions that originated from the results of the research. Five employees from each firm were given self-administered questionnaires for completion, in order to increase the response rate; the questionnaire was precise and simple. In addition, the researchers also made use of Likert-scaled questions to obtain respondents' level of agreement or disagreement on a symmetric agrees-disagree scale for a series of statements. Thus, the range captures the intensity of the respondents' feelings for a given item.

Qualitative research includes an array of interpretative techniques which seek to describe, decode, translate and otherwise come to terms with the meaning, not the frequency of certain more or less naturally occurring phenomena in the social world (Cooper and Schindler 2006, p.214). Qualitative research design enabled the researchers to interview one-on-one, 20 managers of selected private business firms in King Williams Town in determining and understanding their perceptions, insights, attitudes and feelings, concerning HIVIAIDS generally and HIVIAIDS in the workplace, its effect and more importantly, the establishment of their HIVIAIDS work place policy/programmes.

The data generated from this research was analysed at the Department of Statistics, University of Fort Hare. The statistical software used for this analysis was Statistics Package for Social Sciences (SPSS). The Chi-square test is used to determine whether there is a significant difference between the expected frequencies and the observed frequencies in one or more categories (Sharp, 2010, p.1). The same author stated that Chi-square Test requirements are quantitative data, one or more categories, independent observations, adequate sample size (at least 10), simple random sample, data in frequency form and that all observations must be used. The Chi-square test was applied for inferential statistics. Cross tabulations of specific variables were done to get $p$-values. If the $p$-value is less than "alpha" which is typically set at 0.05 then the null hypothesis is rejected and the alternative is accepted (Chen, 2011).

\section{Results and Discussion}

The findings to the purpose and set objectives of this study are whether HIVIAIDS has an impact on the profitability of businesses in emerging economies. The findings of data are presented qualitatively as well as quantitatively. The researchers made use of simple terminology, and percentages, for presentation of the quantitative analysis. Finally, a section on hypotheses testing which provides results for the research findings can be found.

\subsection{Qualitative Data Analysis}

Data gathered from personal interviews was analysed by recording the responses gathered from the respondents, grouping them, based on similarities in responses in order to make sense out of them, and establish the traits that are common. Analysis of a personal interview also entails inferring the reason for certain responses and making conclusions from the feedback. The analysis of the qualitative data was done by analysing the responses on a question-to-question basis.

The interviewers gathered from the responses to the interviews that the majority of the firms do not offer a voluntary HIV test to employees, which implies that generally, firms are not aware of the number of their employees that are living with HIVIAIDS and therefore cannot monitor employees living with HIVIAIDS to ensure that they are placed on medication for them to remain healthy while performing their duties. The interviewers gathered that employees living with HIVIAIDS will have an effect on the profitability of business firms through absenteeism owing to their state of health, loss of key personnel of the business firms and the cost incurred in recruitment and training. Furthermore, the interviewers also gathered that the majority of the firms do not have an HIVIAIDS workplace policy, which indicates that the impact of HIVIAIDS is not properly controlled and minimised by the majority of business firms.

\subsection{Quantitative Data Analysis}

Hypotheses one examined whether employees of business firms in developing nations are not/are aware of issues pertaining to HIVIAIDS. A Chi-square test was performed to test the level of association between the employees and awareness of HIVIAIDS. A Chi-square value of 14.50 with $16 \mathrm{df}$ and a $p$-value of 0.78 was found. Since the $p$-value is above 0.05 , the null hypothesis which states that employees of business firms in developing nations are not aware of issues pertaining to HIVIAIDS is accepted. 
Hypothesis two examined whether business firms in developing nations do not/do have a workplace policy on HIVIAIDS to minimise the impact of HIVIAIDS. Chi-square test of association was performed by cross-tabulating the two variables, which are presence of an HIVIAIDS workplace policy and minimising the impact of HIVIAIDS. The results indicated a Chi-square value of 14.56 with $16 d f$ and a $p$-value of 0.068 . Since the $p$-value is greater than 0.05 , it therefore concludes that the null hypothesis which states that business firms in developing nations do not have any workplace policy on HIVIAIDS to minimise the impact of HIVIAIDS is accepted.

Hypothesis three examined whether HIVIAIDS does not/does affect the profitability of business firms in developing nation in a certain way. A Chi-square test of association was performed by cross-tabulating two variables namely HIVIAIDS and impact on profitability of business firms. The results show a Chi-square value of 15.858 and $8 \mathrm{df}$ with a pvalue of 0.044 . Since the $p$-value is less than 0.05 , it therefore concludes that the alternative hypothesis which states that HIVIAIDS does affect the profitability of business firms in developing nations is accepted.

It was proven from all the findings of all secondary hypotheses tests that indeed HIVIAIDS has an effect on the profitability of business firms in King Williams Town. Thus, from the findings to the other hypotheses, the null hypothesis is rejected and it is concluded that HIVIAIDS does have an impact on profitability of business firms in King Williams Town as part of a developing nation. Based on the findings of this research study, the owners/managers of the private business firms in King Williams Town agree to the fact that they do not offer voluntary HIVIAIDS to employees which implies that these firms are not aware of the employees that are living with HIVIAIDS. The employees are also not aware if they are living with HIVIAIDS or not based on the fact they do not know their HIVIAIDS status just like the firms are also not aware of their HIVIAIDS status. The owners/managers of the private business firms in King Williams Town agreed to the fact that HIVIAIDS has an impact on profitability of their businesses due to their experiences from employees through absenteeism due to their state of health, loss of key personnel and cost incurred during recruitment and training. Also, the employees answered that HIVIAIDS illness and death of a fellow employee can affect their work performance which indicates that they agree to the fact that HIVIAIDS affect profitability of businesses.

The owners/managers of the private business firms in King Williams Town answered that they do not have an HIVIAIDS workplace policy to minimise the impact of HIVIAIDS while the employees answered that the firms they work for do not have an HIVIAIDS workplace policy which indicates that business firms in King Williams Town do not have an HIVIAIDS workplace policy.

The issue of HIVIAIDS can be addressed with confidence because employees' responses are usually surprisingly favourable. Due to the fact that HIVIAIDS is a difficult subject to address, the benefit of an HIVIAIDS workplace policy/programme is that what would have presented a serious employee problem could be addressed effectively and the employees are well positioned to manage the impact of HIVIAIDS, prolonging their own lives and that of their colleagues.

Developing an HIVIAIDS workplace policy/programme is of utmost importance. This should be an initial step for any firm in a developing country in its commitment to address HIVIAIDS issues. The HIVIAIDS workplace policy/programme should clearly state the firm's position on HIVIAIDS and outline responsibilities, rights and behaviour expected from management and employees. This research could provide business firms in emerging economies with the vital information it requires in the development of an HIVIAIDS workplace policy/programme and encourage businesses to have an HIVIAIDS workplace policy/programme.

Necessary implementation, monitoring and evaluation tools must be put in place to prevent the HIVIAIDS workplace policy/programme from being abandoned. Corrective measures needs to be taken if some of the characteristics are not present for the reduction of the impact to be effective.

\section{Recommendations}

Suggestions were made based on the research findings, seeing that HIVIAIDS affects the profitability of business firms; the recommendations are made as follows:

\subsection{Creating HIV/AIDS Awareness}

It is recommended that management should encourage employees and managers to openly discuss HIVIAIDS responsibly and keep them updated about the issues related to HIVIAIDS. Allowing open discussion between employees living with HIVIAIDS and those that are not living with it leads to addressing HIVIAIDS effectively, in order to prevent new infections and reduce the impact of HIVIAIDS. Management could hold a strategic planning workshop to deal with the challenges of managing HIVIAIDS in the business firm which is the firm's priority. Efforts and finance that will be utilised can be discussed. 


\subsection{Minimising the Impact of HIV/AIDS}

HIVIAIDS is a serious health issue in many parts of the world. Most businesses are under pressure due to the increasing impact of HIVIAIDS. Impacts such as an increase in operational costs, health care cost for sick employees, death benefits, recruitment costs and training costs grow as the firm tries to replace lost personnel, thereby reducing a firm's income by lowering productivity of employees and increasing absenteeism.

Again, one of the most damaging features of HIVIAIDS is its impact on morale. Employees are scared of colleagues living with HIVIAIDS for fear of contracting HIVIAIDS and also the reality of watching them die is alarming and depressing. This results to an environment of suspicion, tension discrimination in the work environment.

The management of the selected firms need to consider the impact of HIVIAIDS on profitability because increased cost leads to colossal loss. The selected firms can minimise and manage the impact of HIVIAIDS with the help of findings of this research. Management should encourage employees and managers to contact appropriate resources for answers to questions concerning HIVIAIDS and also, management may offer voluntary HIVIAIDS tests to the employees to at least have an idea of the HIVIAIDS prevalence of the firm and monitor employees living with HIVIAIDS to minimise the impact of the pandemic.

\subsection{Suggestions for Future Research}

This research may stimulate future and further research on the impact of HIVIAIDS on profitability of business firms in other areas and also the use of models, for instance using the AIDS Impact Model for Business (AIM-B) to calculate the impact of HIVIAIDS in business firms which will also assist business firms to derive benefit by the use of such models.

\section{Conclusion}

It can be concluded that the research was conducted to determine HIVIAIDS awareness and its impact on business firms in developing nations and the findings of the research generally were indeed that HIVIAIDS affects the profitability of business firms in developing nations.

\section{References}

Aaron, I. (2007). Preserving Liberty and Protecting Public Health: Examining the Constitutionality of Quarantine and Isolation Plans In Hawai'i. [Online] Available: http://www.law.hawaii.edu/sites/www.law.../SYS_Final_Draft_Karlen.pdf (August 10, 2012).

Arndt, C., \& Lewis, J.D. (2000). The Macro implications of HIVIAIDS in South Africa: A preliminary Assessment. South African Journal of Economics, 68(5), pp.380-392.

Asian Business Coalition on AIDS. (2002). Business taking action to Manage HIVIAIDS. Thailand: Asian Business Coalition.

Bendell, J. (2003). Walking up to Risk: Corporate Responses to HIVIAIDS in the workplace. [Online] Available: http://www.unrisd.org/ 80256b3c005bccf9.nsf/0/8836d5e635b2d234c1256dd6004ee8c1?OpenDocument\&panel=seriespapers\&Click= (May 13, 2013).

Biggs, T., \& Shah, M. (1997). The impact of the AIDS Epidemic on African firms. (Online) Available: http://siteresources.worldbank.org /EXTAFRSUMAFTPS/Resources/rped072.pdf (July 12, 2012).

Bloom, D., Mahal., A. \& River Path Associates. (2001). HIVIAIDS and the Private Sector - A literature review. [Online] Available: http://www.iaen.org/files.cgi/7050b-bloom-private-sector (January 15, 2012).

Cant, M., Gerber-Nel, C., Nel, D., \& Kotze, T. (2008). Marketing Research. Pretoria: Van Schaik Publishers.

Center for Disease Control (CDC). (1984). HIV \& AIDS - The Evolving Definition of AIDS. [Online] Available: http://www.virusmyth.com laids/hiv/rrbdef.htm (April 10, 2012).

Centres for Disease Control. (1985). Revision of the case definition of acquired immunodeficiency syndrome for national reporting. United States. MMWR 34(25):373-375.

Chen, T.T., \& Chen, M.C. (2011). Using chi-square statistics to measure similarities for text categorisation. Expert systems with applications. 38:3085-3090.

Chen, Z. (2011). A new association test based on Chi-square partition for case-control GWA studies. Genet Epidiomiol 35(7):658-63. [Online] Available: http://www.ncbi.nlm.nih.gov/pubmed/22009790 (May 23, 2013).

Cooper, D.R., \& Schindler, P.S. (2006). Marketing Research. New York: McGraw-Hill.

Dey, I. (2005). Qualitative Data Analysis: A User-Friendly Guide for Social Scientists. [Online] Available: www.drapuig.info/files /Qualitative_data_analysis.pdf (January 12, 2012).

Dickinson, D. (2004). Corporate South Africa's Response to HIVIAIDS: Why so slow? Journal of Southern African Studies. $30(2): 1-22$.

Egger, A.E., \& Carpi, A. (2008). Data: Analysis and Interpretation. [Online] Available: http://www.visionlearning.com (October 25, 2012).

Fakier, A. (2004). The Global Reporting initiatives HIVIAIDS reporting guidelines in South Africa Perceptions, uses and possible outcomes. HIVIAIDS in the workplace: Symposium Proceedings University of the Witwatersrand, 29 \& 30 June. Centre for Health 
Policy Johannesburg 87-105.

Fraser-Moleketi, G. (2000). Public Service and HIVIAIDS. Proceedings of the 2000 Greater Johannesburg Metropolitan Council. Johannesburg, Metropolitan Council.

Greener, R. (1997). Impact of HIVIAIDS and Options for Intervention Results of a Five Company Pilot Study. Botswana National Task Force on AIDS at the Workplace. BIDPA Working Paper No. 10.

Hawthorne, P. (1999). A Blighted Generation. TIME Magazine, July 26. [Online] Available: http:// www.time .com (April 20, 2013).

International Aids Economic Network (IAEN). (2002). State of the Art: AIDS and Economic. July 2002. Barcelona. Spain: IAEN.

Jones, C. (1996). Makandi Tea and Coffee Estates Limited: The Microeconomic Implications of HIV/AIDS. Norwich, England: University of East Anglia.

Lani, J. (2009). Quantitative Analysis. [Online] Available: http://www.statisticssolutions.blogspot.com/2009/07/quantitative-analysis.html (January 12, 2012).

Loewenson, R., \& Whiteside, A. (1997). Social and Economic Aspects of HIVIAIDS in Southern Africa. SAfAIDS Occasional Paper Series No. 2. Harare: SAfAIDS.

Lundin, J. (2003). Companies need a deduction approach to AIDS Issues. Financial Mail, 06 December, in Naido0, P. (2005). The Knowledge, Attitude and Training Needs of Line Managers at the South African Sugar Association (SASA) with regards to the Management of HIVIAIDS infected employees. Unpublished MBA Dissertation. Durban: Durban Institute of Technology. [Online] Available: http://ir.dut.ac.za/bitstream/handle/10321/81/Naidoo_2005?sequence=1 (July 23, 2012).

Mamabolo, J.M.S. (2009), Didactic and Linguistic Constraints Pertaining to the Teaching of Southern Ndebele. [Online] Available: http://uir.unisa.ac.za/xmlui/bitstream/handle/10500/1962/04chapter3.pdf (June 14, 2013).

Marcus, R. (2003), Analysing Qualitative Data. [Online] Available: http://www.learningstore.uwex.edu/pdf/g3658-12.pdf (February 12, 2013).

Morris, C., Burdge, D.R., \& Cheevers, E.J. (2000). In Naidoo, P. (2005). The Knowledge, Attitude and Training Needs of Line Managers at the South African Sugar Association (SASA) with regards to the Management of HIVIAIDS infected employees. Unpublished MBA Dissertation. Durban: Durban Institute of Technology. [Online] Available: http://ir.dut.ac.za/bitstream/handle/10321 /81/Naidoo_2005?sequence=1 (July 23, 2012).

Petesch, J.P. (2003). Expert Perspectives: Dealing with HIVIAIDS in the workplace. [Online] Available: http://www.thebody.com/content lart45204.html (February 13, 2012).

Roberts-Lombard, M. (2002). Marketing Research - A Southern African Perspective. Cape Town: Future Managers.

Root-Bernstein, R. (1993). The Evolving Definition of HIVIAIDS: The Tragic Cost of Premature Consensus. New York: Free Press.

SA DOH. (2009). South Africa HIV and AIDS Statistics. [Online] Available: http://www.avert.org/south-africa-hiv-aids-statistics.htm (June 20, 2012).

SABCOHA/BER. (2003). The economic Impact of HIVIAIDS on businesses in South Africa.

Sharp, V. (2010). Chi-Square Test. [Online] Available: http://www.enviroliteracy.org/pdf/materials/1210.pdf (January 20, 2013).

Smith, J., \& Whiteside, A. (1995). The Socioeconomic Impact of HIVIAIDS on Zambian Businesses. London: The BEAD Group and the Commonwealth Development Corporation.

Smith, S. (2012). What is the Meaning of Sample Size? [Online] Available: http//www.ehow.com (April 20, 2012).

Statistics South Africa. (2009). South Africa HIV and AIDS Statistics. [Online] Available: http://www.avert.org/south-africa-hiv-aidsstatistics.htm (January 20, 2013).

The Impact of HIVIAIDS on Business. [Online] Available: http://www.bizcommunity.com/Article/196/309/18373.html (July 14, 2013).

The impact of the HIVIAIDS epidemic on firms. [Online] Available: http://www.un.org/esa/population/publications/.../7_Chap_IV.pdf (April 20, 2012)

The Pan African Health Congress News. (2008). Comments on South Africa. [Online] Available: www.bizcommunity.com/Comments/196 /309.html (June 12, 2012).

Trochim, W.M.K. (2006). Types of surveys. Research Methods Knowledge Base. WebCenter for research methods.

Tustin, D., Ligthelm, A.A., Martins, J.H., \& Van Wyk, H.J. (2005). Marketing Research in Practice. Pretoria: UNISA Press.

UNAIDS. (2000). The Global Business Council on HIV\&AIDS, the Prince of Wales Business Leaders Forum 2000. The Business response to HIVIAIDS: Impact and Lessons Learnt. [Online] Available: http://www.unaids.org/en/default (June 20, 2013).

UNAIDS. (2001). The Impact of HIVIAIDS on the Health Sector in Sub-Saharan Africa: The Issue of Human Resources. From: http://www.ratn.org/index.php?option=com_docman\&task=doc (July 20, 2012).

UNAIDS. (2009). Epidemic Update. [Online] Available: http://www.unaids.org/documents/20101123_globalreport_chap2_em.pdf (November 10, 2012).

UNAIDS. (2010). Epidemic Update - 2010 Global Report. [Online] Available: http://www.unaids.org/documents/20101123_globalreport chap2_em.pdf (April 20, 2012).

UNDESA. (2002). HIVIAIDS and Family Well-Being in Southern Africa: Towards an Analysis of Policies and Responsiveness. [Online] Available: http://www.un.org/esa/socdev/unyin/...Windhoek-backgroundpaper3.pdf (March 10, 2012).

Usaid/African Bureau. (2000). How Does HIVIAIDS Affect African Businesses? [Online] Available: http://www.usaid.gov/pdf_docs IPNACN454.pdf (April 20, 2013).

Weiss, R.A. (1993). "How does HIV cause AIDS?" Science 260 (5112): 1273-9.

Whitefield, B. (2005). Contemporary Issues in Strategic Management. Town: Kagiso Publishers and CCDD at Technikon SA.

World Health Organisation (WHO). (2005). What is HIVIAIDS? - The Medical News. [Online] Available: http://www.newsmedical.net/health/What-is-HIVAIDS.aspx (January 20, 2013). 